functioned for about eight hours a day and its successor a few months later made available, all around the clock, all types of telecommunications between the Pacific Coast of the United States and the Far East. The Pacific satellites have done something more: brought down cable rates. The trans-Pacific charges set by Comsat, the United States Communications Satellite Corporation, were so much lower than those set by the cable carriers that the Federal Communications Commission ordered these to cut their prices or let Comsat take over their business with the American defence department. This is why the American Telephone and Telegraph Company is now preparing another cut in trans-Atlantic rates, presumably to match the satellite competition.

The economics of satellites are uncertain. The first sent over the Pacific was, in a sense, a waste of money (although a failure rate of one in five launchings has been budgeted for). It is no longer in use. But Early Bird has been working a full year longer than expected on the Atlantic run; estimates for the lifetime of satellites have been deliberately pessimistic. The chances that they will be cheaper than anyone thought are probably better than that they will be more expensive.

The recent launch put the fourth INTELSAT II into the sky. (One is over the mid-Atlantic, where it can make up for the inability of Early Bird to provide links with the southern hemisphere as well as simultaneous television and telephone transmission.) The newest has been sent into synchronous equatorial orbit over the Pacific at approximately 175 degrees East. All are about twice the weight of Early Bird, weigh about 192 pounds and are 56 inches in diameter and 26.5 inches high, not counting antennae. Next year, however, the stout string and sealing wax stage should be over for good.

The INTELSAT III series of satellites should by then have been launched, all six of them. Built by TRW Incorporated for a basic price of $\$ 32$ million, these will have three times the capacity of the INTELSAT II satellites and should ensure continuous operation, even if one or even two go dead. By 1969, moreover, the total number of ground stations around the globe is expected to be 40 -including one in Spain, which is also being mentioned as a possible terminus for the new telephone cable.

\section{Victory on Pensions}

The Institution of Professional Civil Servants seems to have won a tangible if modest victory in its dealings with the Department of Education and Science on behalf of scientists working for the research councils who may find themselves being transferred to the British Civil Service. The issue is the ease with which people moving into or out of the Civil Service can retain their pension rights in full. Hitherto transfers of this kind, an increasingly common hazard now that public laboratories of all kinds are beginning to respond to the public clamour for mobility, have been governed by the rule that entitlement to pension is within the discretion of the Civil Service. Although the research councils and the Civil Service operate pensions schemes which are closely similar, and which are in particular non-contributory, it has been possible for the Civil Service to take an awkward line in its dealings with transfers. Sometimes, for example, the question has been raised of whether people leaving a Civil Service laboratory for a job with one of the research councils have had no assurance that the full value of their pensions rights would be transferred. What seems now to have happened is that the Institution of Professional Civil Servants has won the agreement of Mr Patrick Gordon-Walker, Secretary of State at the Department of Education and Science, that transferability would in future be automatic for movements between the Civil Service and the research councils. Transferability between the Civil Service and the research councils on the one hand and the rest of the world on the other continues to be impeded by lack of transfer rights, although it is hard to see how the Fulton Commission on the Civil Service can fail to recommend the abolition of this anomaly.

News of the dispute between the Institution of Professional Civil Servants and the Science Research Council about the pensions rights of those employed at the Daresbury Laboratory is less cheerful. A writ against the council by the institution is due to be heard in the courts later this year. The issue is exceedingly complicated, chiefly because of the reorganization of government science under the Science and Technology Act of 1965. The act was the legal instrument which established the Science Research Council and which transferred to it the activities of the National Institute for Research in Nuclear Science, then the operator of the Rutherford Laboratory at Harwell and the body responsible for building the Daresbury Laboratory. Because the Rutherford Laboratory had grown out of the Atomic Energy Authority's laboratory at Harwell, it had been agreed that employees at the Rutherford Laboratory should retain, if they chose, membership of the contributory pensions scheme operated by the AEA. The need to perpetuate this arrangement under the new legislation was apparently recognized only at a late stage of the passage of the bill through Parliament, and an amending clause was introduced in February 1955. This clause laid down that the right to opt for AEA pensions should apply not merely to those already "employed by the National Institute for Research in Nuclear Science" but also to those subsequently taken on "to work on activities taken over .. . from the National Institute for Research in Nuclear Science", but Lord Snow told the House of Lords at the time that there was no intention that this provision should apply to Daresbury as well as the Rutherford Laboratory. The Institution of Professional Civil Servants has taken issue with the British Government's view that the Act will permit such an interpretation. Whatever the courts decide, it is hard to think that these arrangements will survive the acid test of feasibility, let alone the report of the Fulton Commission now only half a year away.

\section{Aldabra Expedition Returns}

The first phase of the Royal Society expedition to Aldabra, the atoll in the Indian Ocean where the Ministry of Defence proposes to build an air staging post and the $\mathrm{BBC}$ would like a transmitter, is now complete. Seven scientists have returned after spending five weeks on the atoll, making preliminary investigations of numbers and distribution of animals and plants, both on the atoll and in the lagoon. They have come back convinced that Aldabra should be preserved, 
for it is the last place in the Indian Ocean where island life can be studied in isolation.

The expedition landed at the west island, where there has been a settlement since 1888, and from there made excursions to the south and north, and, together with parties from the Ministries of Defence and Public Building and Works, to the east end of the atoll. The aim was for each member to become acquainted with as many habitats as possible. The eastern end proved to be the area of greatest ecological interest. It has the greatest concentration of giant land tortoises, Testudo gigantea. There are apparently more than 10,000 of these tortoises on Aldabra; elsewhere they are only found in the Galapagos Islands. The eastern end has also the greatest number of frigate birds, as many as a thousand birds could be seen hanging above one of the fresh water pools which attract them. The main breeding area of these birds is in the middle island where hundreds of thousands were seen nesting.

This survey work is being continued by four scientists and two technicians of the Royal Society party who remained on Aldabra to carry out the second phase of the expedition. If the Ministry of Defence project is not implemented, a long term thorough ecological survey will be planned; if the project goes ahead the expedition will make the fullest possible ecological survey before the ecology of the atoll is changed by the construction work.

Aldabra has remained untouched because it is so inhospitable to man; the terrain is difficult and apart from rain there is very little drinking water. The proposed developments will be extensive, and the whole ecology will suffer. When construction begins the weeds which are associated with settlements, and which are now contained by the native vegetation, will spread through Aldabra. There will be a flow of foreign weeds and invertebrates into the islands, and the feral mammals now confined to the south and west islands will spread throughout the atoll. When the cats find the flightless rails these birds will not last very long. The danger is not, however, of large scalc extinction; the RAF would make efforts to preserve the giant tortoise and flightless rail, which in any case can be preserved in zoos. The inevitable consequence of construction work will be the destruction of the integrity of an unspoiled island ecosystem. This is the last remaining ecosystem of its kind in the Indian or Pacific Oceans, and that for the Royal Society is reason enough for preserving it.

\section{Money for Chemists}

THe Chemical Society is appealing to its members for money. This is not because of careless accountancyin fact the society seems to have been scrupulously careful-but is one result of a move which the society plans to make to the rooms occupied until recently by the Royal Society in Burlington House. The Royal Society itself has moved to Carlton House Terrace, and most of the rooms left empty have been offered. to the Chemical Society rent free by the British Government. The snag is that the move will be expensive-the society estimates that it will need $£ 300,000$ to adapt and furnish the new rooms, build a new publications warehouse at Letchworth and share the cost of a new lecture theatre in Savile Row. By what it describes as prudent husbanding of its re- sources, the society has saved $£ 125,000$, and is now appealing to its members, to the chemical industry and to charitable trusts for the extra $£ 175,000$.

Chemists who feel that this is an expensive move should reflect that the new rooms will enable the society to group together staff previously distributed all over London. It will also provide a council room and a much larger library. They might also be reminded that it has cost the Royal Society $£ 863,000$ for its move to Carlton House Terrace. $\$ 250,000$ was supplied by the Government, and an equal sum by the Nuffield Foundation, but much of the remainder is still outstanding. Ominously for the Chemical Society's hopes, an appeal to fellows of the Royal Society has not so far produced everything the organizers hoped for. And gratitude to the Government for its generosity in supplying accommodation should perhaps be tempered by the thought that once there were splendid hopes for a home for scientific societies in a science centre on the South Bank. It is a long time since that idea was last heard of.

\section{Temptations of Science}

THE British preoccupation with the need to persuade young people into science and engineering, but particularly the latter, was continued last week by the Research and Development Society, which devoted the second of its one-day symposia to the subject. Adults, at least, are prepared to take the subject seriously, and 150 turned up at Imperial College to listen to a panel of speakers which included many of those whose names are now associated with the definition of various aspects of this problem-Professor Michael Swann, for example, and Mr G. S. Bosworth, Director of Personnel at the English Electric Company. Mr Bosworth was strong in his statement that "technology is not a second-rate science". To pretend otherwise is now, of course the most sure way in which a man can lose his public reputation. But Mr Bosworth also said that engineers are too often diverted from the objectives by irrelevant details in atomic theory, and that industry often mistreats those whom it recruits so that they hurry back to the "world of the PhD". Mr D. A. Head, from the aero-engine division of Rolls Royce, took the line that, however the difficulties of attracting scientists into industry have arisen, only industry can handle the problems thus created, which means that companies must put recruits into the right jobs and make sure that they know about their prospects of promotion.

The symposium seemed to agree about the shortcomings of education in British schools and universities. For one thing, there was a general complaint about early specialization, one of the consequences of which is the alleged reluctance of narrowly educated people in industry to change from one kind of job to another. On the whole, those attending the conference took the view that specialization should be postponed until 18. There was also a general feeling that science courses at universities should be broadened so as to provide students with an appreciation of other kinds of studies and of social problems of various kinds. One speaker went so far as to say that the British educational system is designed to produce "cultured gentlemen", with the result that trained scientists consider that collaboration is a kind of cheating, that engineering is inferior and that the profit motive is even worse. 